\title{
PCDH7 wt Allele
}

National Cancer Institute

\section{Source}

National Cancer Institute. PCDH7 wt Allele. NCI Thesaurus. Code C122004.

Human PCDH7 wild-type allele is located in the vicinity of 4 p15 and is approximately 426

$\mathrm{kb}$ in length. This allele, which encodes protocadherin-7 protein, is involved in the

modulation of cell-cell adhesion. 